4 Amiuo $\mathrm{N}$, Tanizawa $\mathrm{O}$, Mori $\mathrm{H}$, et al. Aggravation of thyrotoxicosis in early pregnancy and after delivery in Graves' disease. $\mathcal{F}$ Clin Endocrinol Metab 1982;55:108-12.

5 Bouillon R, Naesens M, van Assche FA, $e t$ al. Thyroid function in patients with hyperemesis gravidarum. Am f Obstet Gynecol 1982;143:922-6.

(Accepted 28 January 1987)

Prince of Wales Hospital, Shatin, Hong Kong

T T H LAO, MRCOG, lecturer in obstetrics and gynaecology

R K H CHIN, MRCOG, senior medical officer in obstetrics and gynaecology

R SWAMINATHAN, PHD, MRCPATH, reader in chemical pathology

N S PANESAR, PHD, lecturer in chemical pathology

C S COCKRAM, BSC, MRCP, senior lecturer in medicine

Correspondence to: Dr Lao.

\section{Haemodynamic changes during the early puerperium}

The early puerperium is a time of dramatic haemodynamic readjustment. A $20-30 \%$ increase in cardiac output above prelabour levels has been reported during the first 24 hours after delivery. ${ }^{1}$ Subsequent changes have been inadequately documented. We therefore investigated the haemodynamic changes during the first two weeks after vaginal delivery.

\section{Patients, methods, and results}

Ten healthy women with uncomplicated singleton pregnancies were studied at 38 weeks' gestation and then 48 hours and two weeks after normal delivery. Investigations were performed using an echocardiographic Doppler system (Hewlett-Packard 77500B) with the subjects in the semi-left lateral position after at least 15 minutes' rest. No patient received more than $1500 \mathrm{ml}$ intravenous fluid during labour, and in all cases the estimated blood loss at delivery was less than $300 \mathrm{ml}$.

Cardiac output was determined by Doppler ultrasound measurement of ascending aortic blood velocity combined with cross sectional echocardiographic measurement of the aortic area. The technique has been validated in vivo ${ }^{2}$ and allows easily repeatable, non-invasive measurements of cardiac output. Aortic velocity was measured with continuous wave Doppler ultrasound by a transducer placed in the suprasternal notch. The area under the velocity curve (velocity integral) was determined with a digitising tablet. The average of 8-10 consecutive beats was used for each determination. The diameter of the aortic orifice was measured during systole from a cross sectional echocardiograph (parasternal long axis plane). Diameters from five consecutive beats were averaged. Aortic cross sectional area was calculated from the equation $\pi \times(D / 2)^{2}$, where $D=$ mean aortic diameter. Heart rate was determined from the $R-R$ interval of a simultaneously recorded electrocardiogram. Cardiac output was then calculated according to the formula: cardiac output $(\mathrm{ml} / \mathrm{min})=$ stroke volume $(\mathrm{ml}) \times$ heart rate $\left(\mathrm{min}^{-1}\right)$, where stroke volume $(\mathrm{ml})=$ velocity integral $(\mathrm{cm}) \times$ cross sectional area $\left(\mathrm{cm}^{2}\right)$.

End systolic and end diastolic dimensions were measured from standard left ventricular $M$ mode echocardiographs. ${ }^{3}$ Ejection fraction and mean rate of circumferential fibre shortening, two indices of myocardial contractility, were calculated. ${ }^{4} \mathrm{~A}$ repeated measures analysis of variance was performed for each variable. No transformation to normality was necessary for the data.
The cross sectional and Doppler echocardiographic results are shown in the table. Heart rate fell significantly after delivery, reaching values $14 \%$ (48 hours) and $26 \%$ ( 2 weeks) below those obtained at the end of pregnancy. Stroke volume was significantly increased at 48 hours $(10 \%)$ and thereafter declined, reaching values two weeks after delivery $16 \%$ lower than those at 48 hours. The increase in stroke volume was due to a significant increase in velocity integral (13\%). Cardiac output remained raised 48 hours after delivery. By two weeks cardiac output had decreased by $13 \%$ relative to the end of pregnancy. End diastolic dimension was significantly increased at $\mathbf{4 8}$ hours. Ejection fraction and mean rate of circumferential fibre shortening showed no significant change 48 hours after delivery but thereafter both showed a significant decrease.

\section{Comment}

Our results indicate that cardiac output remains raised for at least 48 hours after normal delivery owing to an increase in stroke volume and despite a coexistent fall in heart rate. The increase in end diastolic dimension suggests an increase in venous return perhaps due to the autotransfusion from the uteroplacental vascular bed after delivery. This augmentation of venous blood return might be responsible for the increase in stroke volume.

By two weeks cardiac output had shown a significant fall due to a decline in stroke volume and a further reduction in heart rate. During the same period there was a fall in end diastolic dimension, a change which probably reflects the decrease in circulating volume found during the first weeks of the puerperium. Myocardial contractility also appeared to be reduced two weeks after delivery when compared with values at the end of pregnancy. This interesting observation, which has been reported previously, ${ }^{5}$ may reflect a decrease in end diastolic volume (the Frank-Starling effect) or it might represent a true diminution in myocardial function. The new observations reported in this study may have important implications for the puerperal management of women with pre-cxisting heart disease or postpartum cardiomyopathy.

We thank Dr R Boys for his statistical advice. The work was supported by a grant from Newcastle Health Authority.

1 Kjeldsen J. Haemodynamic investigations during labour and delivery. Acta Obstet Gynecol Scand 1979;89 (suppl): 144-53.

2 Huntsman LL, Stewart DK, Barnes SR, Franklin SB, Colocousis MD, Hessel EA. Noninvasive doppler determination of cardiac output in man: clinical validation. Circulation 1983;67:593-602. 3 Popp RL, Harrison DC. Ultrasonic cardiac echography for determining stroke volume and valvular regurgitation. Circulation 1970;41:493-502.

4 Karliner JS, Gault JH, Eckberg D, Mullins CB, Ross J. Mean velocity of fibre shortening. A simplified measure of left ventricular myocardial contractility. Circulation 1971;44:323-33.

5 Burg JR, Dodek A, Kloster FE, Metcalfe J. Alterations in systolic time intervals during pregnancy. Circulation 1974;49:560-4.

(Accepled 3 February 1987)

University Department of Obstetrics and Gynaecology, Princess Mary Maternity Hospital, Newcastle upon Tyne

SC ROBSON, MB, BS, research registrar

W DUNLOP, PHD, FRCOG, professor

Freeman Hospital, Newcastle upon Tyne

S HUNTER, FRCP, consultant paediatric cardiologist

Correspondence to: Dr Robson.

\begin{tabular}{|c|c|c|c|c|c|c|c|}
\hline & \multirow{2}{*}{$\begin{array}{l}\text { Pregnancy } \\
38 \text { weeks } \\
\text { (38) }\end{array}$} & \multicolumn{2}{|c|}{ Postnatal } & \multirow[b]{2}{*}{ SEM } & \multicolumn{3}{|c|}{ p Values } \\
\hline & & $\begin{array}{l}48 \text { hours } \\
\text { (48) }\end{array}$ & $\begin{array}{l}2 \text { weeks } \\
\text { (2) }\end{array}$ & & 38048 & $38 v 2$ & $48 v 2$ \\
\hline $\begin{array}{l}\text { Heart rate (beats/min) } \\
\text { Aortic orifice area }\left(\mathrm{cm}^{2}\right) \\
\text { Aortic velocity integral }(\mathrm{cm}) \\
\text { Aortic stroke volume }(\mathrm{ml}) \\
\text { Aortic cardiac output }(\mathrm{l} / \mathrm{min}) \\
\text { End systolic dimension }(\mathrm{cm}) \\
\text { End diastolic dimension }(\mathrm{cm}) \\
\text { Ejection fraction }(\%) \\
\text { Mean rate of circumferential fibre shortening (diameter/s) }\end{array}$ & $\begin{array}{l}86 \\
4 \cdot 45 \\
19 \cdot 6 \\
87 \cdot 4 \\
7 \cdot 46 \\
3 \cdot 19 \\
4 \cdot 79 \\
70 \\
1 \cdot 25\end{array}$ & $\begin{array}{c}75 \\
4 \cdot 35 \\
22 \cdot 2 \\
96 \cdot 1 \\
7 \cdot 22 \\
3 \cdot 26 \\
4 \cdot 95 \\
71 \\
1 \cdot 19\end{array}$ & $\begin{array}{c}64 \\
4 \cdot 26 \\
18 \cdot 9 \\
81 \cdot 1 \\
5 \cdot 16 \\
3 \cdot 24 \\
4 \cdot 70 \\
67 \\
1 \cdot 08\end{array}$ & $\begin{array}{l}2 \\
0.06 \\
0.6 \\
3 \cdot 3 \\
0 \cdot 21 \\
0.04 \\
0.04 \\
1 \\
0.08\end{array}$ & $\begin{array}{l}<0.01 \\
\text { NS } \\
<0.01 \\
<0.05 \\
\text { NS } \\
\text { NS } \\
<0.01 \\
\text { NS } \\
\text { NS }\end{array}$ & $\begin{array}{l}<0.001 \\
<0.05 \\
\text { NS } \\
\text { NS } \\
<0.001 \\
\text { NS } \\
\text { NS } \\
<0.05 \\
<0.001\end{array}$ & $\begin{array}{l}<0.01 \\
\quad N S \\
<0.001 \\
<0.001 \\
<0.001 \\
\quad \text { NS } \\
<0.001 \\
<0.01 \\
<0.01\end{array}$ \\
\hline
\end{tabular}

Values quoted are means. Standard error of the mean (SEM) was determined from the analysis of variance and was based on the intrapatient variability. $p$ (Probability) values were determined by comparing the mean difference between time points with the least significant difference calculated from the residual mean square $(\mathrm{df}=18)$. 